\title{
ECOLOGICAL RESTORATION IN AREA DOMINATED BY Pteridium aquilinum (L.) Kuhn IN CAPARAÓ NATIONAL PARK, MG'
}

\author{
Jeane de Fátima Cunha Brandão ${ }^{2 *}$, Sebastião Venâncio Martins ${ }^{3}$, Isac Jonatas Brandão ${ }^{4}$ and Waldomiro de \\ Paula Lopes ${ }^{5}$

\footnotetext{
${ }^{1}$ Received on 27.01.2015 accepted for publication on 11.11.2016.

${ }^{2}$ Universidade Federal de Viçosa, Doutorado em Ciência Florestal, Viçosa, MG - Brasil. E-mail: <jeanefcunha@yahoo.com.br>.

${ }^{3}$ Universidade Federal de Viçosa, Departamento de Engenharia Florestal, Viçosa, MG - Brasil. E-mail: <venancio@ufv.br>.

${ }^{4}$ Faculdade de Ciências Gerenciais de Manhuaçu, Manhuaçu, MG - Brasil. E-mail: <isacbrand@yahoo.com.br>.

${ }^{5}$ Parque Nacional do Caparaó, Alto Caparaó, MG - Brasil. E-mail: <waldomiro.lopes@icmbio.gov.br>.

*Corresponding author.
}

\begin{abstract}
The goal of this study was to restore an area dominated by P. aquilinum in the National Park of Caparaó, by nucleation techniques. In an area covered by P. aquilinum, 60 nuclei or gaps of 2 x $2 \mathrm{~m}$ were cleared, i.e., 10 nuclei per treatment. In these open areas, all $P$. aquilinum cover was removed down to the soil. In the center of each gap was delimited one parcel of $1 \times 1 \mathrm{~m}$, in which the treatments were applied: T1- liming, T2- seed bank and litter transposition, T3- direct-seeding, T4-liming + seed bank and litter transposition, T5-liming + direct-seeding, T6- control. The experiment was arranged in a completely randomized design with 10 replications. In each nucleation plot, after one year, all arbustive-arboreous species were recorded, by measuring plant height and diameter at ground level. The plants were classified according to the succession class and dispersion type. One year after the installation of the nucleation experiment, 331 individuals of 19 species, 12 genera and 10 botanical families were recorded. Pioneer plants were the predominant ecological group, and the prevailing dispersion type was zoochoric. The richest families were Solanaceae and Euphorbiaceae. Solanaceae was represented by the highest number of individuals $(56.2 \%)$, followed by Fabaceae (10\%). The genus Solanum had the highest richness and abundance. The applied nucleation techniques triggered the succession process in the area invaded by $P$. aquilinum. Treatments with seed banks were the most appropriate to facilitate forest regeneration in this area.
\end{abstract}

Keywords: Inhibition; Fern; Nucleation.

\section{RESTAURAÇÃo ECOLÓGICA EM AREA DOMINADA POR Pteridium aquilinum (L.) Kuhn NO PARQUE NACIONAL DO CAPARAÓ, MG}

\begin{abstract}
RESUMO - O estudo objetivou aplicar técnicas de nucleação para restauração de uma área dominada por P. aquilinum no Parque do Caparaó. Na área ocupada por P. aquilinum, abriram-se sessenta núcleos de $2 \times 2 \mathrm{~m}$, sendo dez núcleos para cada tratamento avaliado. Nestas áreas abertas, toda a cobertura de $\boldsymbol{P}$. aquilinum foi removida até atingir o solo. No centro de cada clareira foi delimitado uma parcela de $1 x$ $1 \mathrm{~m}$, em que foram aplicados os tratamentos: T1-calagem, T2-Transposição do banco de sementes e serapilheira, T3-semeadura direta, T4-calagem + transposição do banco de sementes e serapilheira, T5-calagem + semeadura direta, T6-Testemunha. Adotou-se o delineamento inteiramente casualizado com 10 repetições por tratamento. Em cada parcela da nucleação, após um ano, registraram-se todos os indivíduos arbustivo-arbóreos, medidos em altura e diâmetro ao nível do solo. As plantas foram classificadas quanto à classe sucessional e a sindrome de dispersão. Após um ano da implantação do experimento de nucleação, foram registrados 331 indivíduos arbustivo-arbóreos pertencentes a 19 espécies, 12 gêneros e dez famílias botânicas. Predominou o grupo ecológico das pioneiras e a síndrome de dispersão zoocórica. As famílias com maior riqueza foram Solanaceae e Euphorbiaceae. Solanaceae também se destacou com maior número de indivíduos (56,2\%), seguida de
\end{abstract}


Fabaceae (10\%). O gênero Solanum apresentou maior riqueza e abundância. As técnicas de nucleação adotadas desencadearam o processo de sucessão na área invadida por P. aquilinum. Os tratamentos com banco de sementes foram os mais indicados para facilitar o processo de regeneração florestal na área.

Palavras chaves: Inibição; Samambaia; Nucleação.

\section{INTRODUCTION}

The degradation of forests has contributed to emergence and dissemination of $P$. aquilinum (L.) Kuhn, popularly known as eagle fern. In almost all Brazilian states, the occurrence of such species has been recorded (Lorenzi, 1991), being predominant in open and altered areas and generally in poor, acid, sandy, well drained soils with low levels of calcium and phosphorus (Tokarnia et al., 2000). In the southeast region of Brazil, grasses and ferns are commonly found in disturbed areas, abandoned pastures and on the edge of remnant forest fragments (Silva and Silva-Matos, 2006).

In $P$. aquilinum dominated areas, the process of forest regeneration may not occur or be very slow due to strong inhibition. It has been evidenced that the dense sub-forest layer formed by ferns increases its impact over succession, decreasing the amount of seeds that reach the soil surface and by the increasing shading (Marrs and Watt, 2006). Their rhizomes are underground, which facilitates their rapid proliferation, constituting a physical barrier to root penetration of native species, in addition to reducing the supply of nutrients to them due to competition (Den Ouden, 2000). P. aquilinum also produces allopathic substances that may hinder the germination and establishment of arboreal species (Silva and SilvaMatos, 2006).

The Caparaó National Park has faced problems due to the invasion of $P$. aquilinum, which usually occurs after the occurrence of fires, forming large populations. This species has also invaded the planting areas of the region's farmers around the park, a problem that is difficult to overcome.

Few researches on the methodologies used to control P. aquilinum have been found in Brazil. Therefore, knowledge of the most appropriate restoration techniques for these areas is very useful. Among the techniques used to restore degraded areas are nucleation, which can be pointed mainly to not very extensive areas and inserted in a forest matrix (Martins, 2009a). These techniques are based on the facilitation model, in which one or more species introduced into a particular degraded area modify the environmental conditions facilitating the establishment of other species (Connell and Slatyer, 1977; Martins, 2009a).

Nucleation can be carried out by planting seedlings, seeds, branch transplanting, transposition of the soil seed bank, transposition of seed rain and use of natural and artificial perches (Martins, 2009a). In addition to their low cost, some nucleation techniques have the advantage of promoting the introduction, in a degraded area, of a high density of seeds of several native species and the introduction of reproductive structures, such as root pieces with regrowth capacity.

Seed bank transposition has been widely studied and recommended to form vegetation nuclei in abandoned pastures (Miranda Neto et al., 2010) and in areas degraded by mining (Martins et al., 2008). However, the application of these and other methodologies that promote the formation of vegetation nuclei in an area dominated by $P$. aquilinum is still practically non-existent.

Therefore, by considering the aggressiveness of ferns and the few existing studies on restauration of areas dominated by such species, the objective of this study was to evaluate the use of nucleation techniques to stimulate the succession in an area in Caparaó National Park dominated by $P$. aquilinum, indicating the most adequate one.

\section{MATERIALAND METHODS}

\subsection{Study area}

The study was carried out in Caparaó National

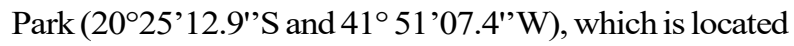
on the border between the states of Espírito Santo and Minas Gerais, occupying seven cities in the state of Espírito Santo and four in the state of Minas Gerais (IBAMA, 2004). It was created in 1961 and has 26,000 hectares, being an important Environmental Conservation Unit in Brazil. Its altitude varies between 997 meters at its lowest elevation, reaching 2,891.9 meters at Pico da Bandeira, which is the third highest peak in Brazil. 
The climate in Caparaó National Park is Cwb (Köppen), altitude tropical. It has mild temperatures, with annual averages between 19 and $22^{\circ} \mathrm{C}$, with absolute maximum reaching $36^{\circ} \mathrm{C}$ and $-4^{\circ} \mathrm{C}$ as the absolute minimum at the highest peaks. Rainfall is around $1,200 \mathrm{~mm}$ annually, and the highest rainfall occurrences are between November and January (IBAMA, 2004).

On the eastern side of the Caparaó massif, located in the state of Espírito Santo, the tropical rain forest predominates and on the west face, in the state of Minas Gerais, according to altitude: up to $1,800 \mathrm{~m}$, Tropical Rain Forest; from 1,800 to 2,400 m, altitude fields with shrub formations; and above $2,400 \mathrm{~m}$, clean fields embedded between the rocky outcrops. The dominant soils are: Dystrophic Yellow Red Latosol, Dystrophic Dark Red Latosol and Red Yellow Podzolic, of low to medium fertility (IBAMA, 2004).

The Atlantic Forest stretch where the research was carried out is located in Minas Gerais $\left(20^{\circ} 25^{\prime} 0.43^{\prime \prime} \mathrm{S}\right.$ and $\left.41^{\circ} 51^{\prime} 3,78^{\prime \prime} \mathrm{W}\right)$, it has a height of 1345 meters and is classified as a Seasonal Semideciduous Montane Forest (Veloso et al., 1991) and has been in the process of regeneration since 1961 . The study area has three hectares and is configured as a large anthropic clearing within a forest matrix where the secondary succession has been inhibited by P. aquilinum for 50 years, forming a biomass layer of 0.80 meters of height and with individuals of $P$. aquilinum reaching up to 3 meters in height, characterizing a typical inhibition model (Connell and Slatyer, 1977). There are indications that the invasion of $P$. aquilinum occurred after the occurrence of a forest fire 50 years ago.

\subsection{Nucleation experiment}

In the area occupied by $P$. aquilinum, ten $2 \times 2$ m nuclei, per treatment, were opened, with a spacing of $5 \mathrm{~m}$ between nuclei. In these open areas, all Pteridium aquilinum cover was removed up to the ground.

At the center of each nucleus, a $1 \times 1 \mathrm{~m}$ plot was delimited, in which the following treatments were applied: $\mathrm{T} 1$ (Liming): in this treatment $300 \mathrm{~g}$ of limestone were applied per plot into the soil, sixty days before the experiment had been set up. To verify the need for performing liming, ten soil samples were collected at a depth of $20 \mathrm{~cm}$ using the Dutch auger, and wrapped in a plastic bag and sent to the Soil Analysis Laboratory of the Federal University of Viçosa for analysis; T2 (seed bank and litter transposition): for transposition, twenty samples were collected from the seed bank of the surrounding forest, at a depth of $5 \mathrm{~cm}$ (Martins, 2009 b) and twenty litter samples were collected with the aid of a hoe and a $1.0 \mathrm{~m}^{2}$ template (wood frame) randomly thrown on the forest ground floor, keeping a distance of $50 \mathrm{~m}$ from the edge of the fragment, however. Then, the samples were packed in black plastic bags and immediately transported and deposited in the identified parcels; T3 (direct sowing): in this treatment, twenty seeds of Araucaria angustifolia were sown in each plot from LARF (Forest Restoration Laboratory) of the Federal University of Viçosa. This species was chosen because it is native to the region; T4 (liming + seed bank and litter transposition): in treatment four, the liming and, later, the transposition of the seed and litter bank were carried out, following the same methodology of treatments 1 and 2; T5 (liming + direct seeding): in this treatment, limestone was also applied, and later, the direct sowing of Araucaria angustifolia was carried out, following the same methodology of treatments 1 and 3; T6 (Control): in treatment six, only the removal of $P$. aquilinum cover was carried out.

A completely randomized design with 10 replicates per treatment was adopted, totaling 60 plots. For the distribution of the treatments in the plots, the treatment and the repetition were written on 60 plastic labels. Immediately after that, they were placed in a plastic bag and mixed. A plastic label was raffled for each plot. The treatments were applied to the plots on November 23, 2011. Every three months, maintenance was performed in the area, removing all $P$. aquilinum individuals around the plots.

\subsection{Collection and data analysis}

After one year, the shrub-arboreal individuals were recorded, measured, measured for height and diameter at the soil level, and plant material was also collected for identification in the VIC herbarium of the Federal University of Viçosa or by literature and expertise consultation. The species were classified in families and had the scientific names and their respective authors updated by the Missouri Botanical Garden database, through the site www.tropicos.org, according to the Angiosperm Phylogeny Group III system (APG III, 2009). The species were classified according to habit (tree and shrub), dispersion syndrome (zoochory, anemochory and autochory) (van der Pijl, 1982) and successional

Revista Árvore. 2017;41(1):e410104 
group (pioneer, early secondary and late secondary), as proposed by Martins and Rodrigues (2002). Regarding grasses and herbs, only coverage (\%) was estimated in each plot.

In addition, phytosociological parameters (density, frequency, dominance and importance value) (MuellerDombois and Ellenberg 1974), Shannon-Wiener's diversity index (H') (Magurran, 1988) and equability (J') (Pielou, 1975) were also calculated through FITOPAC 2.1 program (Shepherd, 2010).

Means of number of individuals and shrub-tree species, height averages and soil height diameter (DAS), as well as the percentage of herbaceous and grass cover in the six treatments were compared through Analysis of Variance (ANOVA), using the F test and later, the Tukey test was applied at the level of 5\% of significance. Statistical analyzes were performed through the STATISTICA 7.0 program (Statsoft, 2004).

\section{RESULTS}

This study recorded 331 individuals belonging to 19 species (14 of bush habit and 5 of arboreal habit), 12 genera and 10 botanical families (Table 1). The families with the highest levels of richness were Solanaceae (five species) and Euphorbiaceae (4). Solanaceae also excelled in the largest number of individuals, with 186 (56.2\%), followed by Fabaceae, with 33 (10\%). Genus Solanum presented the highest level of richness and abundance.

Solanum mauritianum was the most abundant species with $49.6 \%$ of the individuals and also excelled for presenting the highest importance value (45.5\%), followed by Senna spectabilis with $9.7 \%$ of the individuals and the second largest importance value (6.69\%) (Table 1). Sapium glandulatum, Manihot pilosa and Senna alata presented only one individual each.

Treatments 2 (seed bank and litter transposition) and 4 (liming + seed bank and litter transposition) showed the largest number of individuals with 153 and 144 individuals, respectively, corresponding to $89.7 \%$ of the total individuals, in which Solanum mauritianum obtained the highest abundance (156) (Table 2).

The most important ecological group, considering all the treatments, was that of the pioneers, both in relation to number of individuals $(98.8 \%)$ as shrubtree species (94.7\%) as well (Table 2). Considering each treatment, pioneer species were also predominant, in which for five of them, $100 \%$ of the species belong to this ecological group (Figure 1A). Only one early secondary species (Annona cacans) was recorded and no late secondary species were sampled.

In the sowing treatments ( 3 and 5 ), only $4.3 \%$ of Araucaria Angustifolia seeds germinated.

Overall, in the distribution of species and individuals by dispersion syndrome, the highest proportion was shown by zoochory class, followed by the autochory class and anemochory (Table 2).

When analyzing each treatment individually, it was observed that, except for treatment 3 (direct sowing), the species with a zoochory dispersion syndrome stood out in all others. In treatment 1 (liming) and 6 (control), $100 \%$ of the species were zoochoryc (Figure 1B).

Anemochoryc species were recorded in treatments 2 (seed bank and litter transposition), 3 (direct sowing), 4 (liming + seed bank and litter transposition) and 5 (liming + sowing) (Figure 1B), in which Vernonanthura diffusa was present in all these treatments (Table 2). Only in treatments 2 and 4, both with seed banks, autochroryc species were sampled (Figure 1B).

Treatments 2 and 4, both with seed bank, differed statistically from the others for both species richness and number of individuals (Figure 2).

The treatments with the lowest percentage of herbaceous species were 2 (seed bank and litter transposition) and 4 (liming + seed bank and litter transposition), and a statistically significant difference was observed among the others (Table 3A).

Treatments 2 and 4 also excelled for height, statistically differing among the other treatments. In relation to diameter from up ground (DAS), treatments 2 and 4 were statistically equal to 1 and 6 and different from 3 and 5 (Table $3 \mathrm{~B}$ ).

After soil analysis, the following values were observed: $\mathrm{pH}=4.79$; phosphorus $(\mathrm{P})=1.0 \mathrm{mg} / \mathrm{dm}^{3}$, potassium $(\mathrm{K})=54 \mathrm{mg} / \mathrm{dm}^{3}$, exchangeable calcium $\left(\mathrm{Ca}^{2+}\right)$ $=0.31 \mathrm{mg} / \mathrm{dm}^{3}$ exchangeable magnesium $\left(\mathrm{Mg}^{2+}=0.26\right.$ $\mathrm{cmol}_{\mathrm{c}} / \mathrm{dm}^{3}$; exchangeable aluminum $(\mathrm{Al} 3+)=1.17 \mathrm{cmol}_{\mathrm{c}} /$ $\mathrm{dm}^{3}$; potential acidity $(\mathrm{H}+\mathrm{Al})=9.7 \mathrm{cmol}_{\mathrm{c}} / \mathrm{dm}^{3}$; sum of exchangeable bases $(\mathrm{S})=0.71 \mathrm{cmol}_{\mathrm{c}} / \mathrm{dm}^{3}$; Effective Cation Exchange Capacity $(\mathrm{t})=1.88 \mathrm{cmol} / \mathrm{dm}^{3}$; cation exchange capacity at $\mathrm{pH} 7(\mathrm{~T})=10.41$; Base Saturation 
Ecological restauration in area dominated...

Table 1 - Phytosociological parameters of the species recorded in the plots 12 months after treatment application for restoration of an Atlantic Forest area in Caparaó National Park, Minas Gerais. NI = number of individuals; RD $=$ relative density; $\mathrm{RF}=$ relative frequency; $\mathrm{RDo}=$ relative dominance and $\mathrm{IV}=$ importance value.

Tabela 1 - Parâmetros fitossociológicos das espécies registradas nas parcelas, aos 12 meses, após a aplicação dos tratamentos na restauração de uma área de Mata Atlântica no Parque Nacional do Caparaó, MG. NI = número de indivíduos; $D R=$ densidade relativa; $F R=$ frequência relativa; DoR $=$ dominância realtiva; e VI = valor de importância.

\begin{tabular}{|c|c|c|c|c|c|c|}
\hline Families & Specie & NI & $\mathrm{RD}(\%)$ & $\mathrm{RF}(\%)$ & $\mathrm{RDo}(\%)$ & IV $(\%)$ \\
\hline ANNONACEAE & Anonna cacans Warm. & 4 & 1,21 & 2,38 & 0,30 & 1,30 \\
\hline ARAUCARIACEAE & Araucária angustifolia (Bertol.) Kuntze & 17 & 5,14 & 4,76 & 0,51 & 3,47 \\
\hline \multirow[t]{2}{*}{ ASTERACEAE } & Vernonanthura diffusa (Less.) H. Rob. & 6 & 1,81 & 9,52 & 2,62 & 4,65 \\
\hline & Vernonia polyanthes (Spreng.) Less. & 16 & 4,83 & 7,14 & 2,75 & 4,91 \\
\hline \multirow[t]{4}{*}{ EUPHORBIACEAE } & Croton floribundus Lund ex Didr. & 11 & 3,32 & 4,76 & 3,70 & 3,93 \\
\hline & Croton urucurana Baill. & 7 & 2,11 & 4,76 & 7,82 & 4,90 \\
\hline & Manihot pilosa Pohl & 1 & 0,30 & 2,38 & 0,91 & 1,20 \\
\hline & Sapium glandulatum (Vell.) Pax & 1 & 0,30 & 2,38 & 0,12 & 0,94 \\
\hline \multirow[t]{2}{*}{ FABACEAE } & Senna alata (L.) Roxb. & 1 & 0,30 & 2,38 & 0,36 & 1,02 \\
\hline & $\begin{array}{l}\text { Senna spectabilis (DC) H. S. Irwin \& } \\
\text { Barneby }\end{array}$ & 32 & 9,67 & 4,76 & 5,64 & 6,69 \\
\hline LAMIACEAE & Aegiphila sellowiana Cham. & 2 & 0,60 & 4,76 & 0,30 & 1,89 \\
\hline MELASTOMATACEAE & Leandra purpurascens (DC) Cogn. & 6 & 1,81 & 4,76 & 2,58 & 3,05 \\
\hline SALICACEAE & Casearia sylvestris Swartz & 26 & 7,85 & 7,14 & 2,42 & 5,80 \\
\hline \multirow[t]{5}{*}{ SOLANACEAE } & Solanum cernuum Vell. & 7 & 2,11 & 4,76 & 0,56 & 2,48 \\
\hline & Solanum sp. & 5 & 1,51 & 4,76 & 0,50 & 2,26 \\
\hline & Solanum leucodendron Sendtn. & 2 & 0,60 & 2,38 & 0,22 & 1,07 \\
\hline & Solanum mauritianum Scop. & 164 & 49,55 & 11,90 & 65,22 & 45,50 \\
\hline & Solanum Swartzianum Roem. \& Schult & 8 & 2,42 & 4,76 & 1,54 & 2,91 \\
\hline URTICACEAE & Cecropia hololeuca Miq. & 15 & 4,53 & 9,52 & 1,94 & 5,33 \\
\hline
\end{tabular}

Source: research data.

Table 2 - List of species with their respective classification according to life form (LF), ecological group (EG), dispersion type (DT), total number of plants per treatment. $\mathrm{Bu}=\mathrm{Bush} ; \mathrm{Tr}=$ tree; $\mathrm{P}=$ pioneer; $\mathrm{Sc}=$ early secondary. Zoo = zoochory; Ane = anemochory; Aut = autochory. T1 - liming, T2- seed bank and litter transposition, T3- directseeding, T4-liming + seed bank and litter transposition, T5-liming + direct-seeding, T6- control.

Tabela 2 - Lista de espécies com as respectivas classificações em forma de vida (FV), grupos ecológicos (GE), síndrome de dispersão (SD), número total de indivíduos por tratamento. Ab = Arbusto; Av = Arvore; $P=$ pioneira; $S c$ = Secundária inicial. Zoo = Zoocoria $;$ Ane = Anemocoria $;$ Aut =Autocoria. T1-calagem, T2-Transposição banco de sementes e serapilheira, T3-semeadura direta, T4-calagem +transposição banco de sementes e serapilheira, T5-calagem+semeadura, T6-Testemunha.

\begin{tabular}{|c|c|c|c|c|c|c|c|c|c|}
\hline \multirow[t]{2}{*}{ Specie } & \multirow[t]{2}{*}{ LF } & \multirow[t]{2}{*}{ EG } & \multirow[t]{2}{*}{ DT } & \multicolumn{6}{|c|}{$\mathrm{N}^{\circ}$ individuals / Treatments } \\
\hline & & & & $\mathrm{T} 1$ & $\mathrm{~T} 2$ & T 3 & $\mathrm{~T} 4$ & T 5 & T 6 \\
\hline Aegiphila sellowiana & $\mathrm{Tr}$ & $\mathrm{P}$ & Zoo & 1 & & & 1 & & \\
\hline Anonna cacans Warm. & $\mathrm{Tr}$ & $\mathrm{Sc}$ & Zoo & & 4 & & & & \\
\hline Araucaria angustifolia & $\operatorname{Tr}$ & $\mathrm{P}$ & Zoo & & & 8 & & 9 & \\
\hline Casearia sylvestris & $\operatorname{Tr}$ & $\mathrm{P}$ & Zoo & & 10 & & 15 & & 1 \\
\hline Cecropia hololeuca & $\operatorname{Tr}$ & $\mathrm{P}$ & Zoo & 1 & 11 & & 2 & 1 & \\
\hline Croton floribundus & $\operatorname{Tr}$ & $\mathrm{P}$ & Aut & & 3 & & 8 & & \\
\hline Croton urucurana & $\operatorname{Tr}$ & $\mathrm{P}$ & Aut & & 4 & & 3 & & \\
\hline Leandra purpurascens & $\mathrm{Bu}$ & $\mathrm{P}$ & Zoo & & 2 & & 4 & & \\
\hline Manihot pilosa & $\mathrm{Bu}$ & $\mathrm{P}$ & Zoo & & 1 & & & & \\
\hline Sapium glandulatum & $\operatorname{Tr}$ & $\mathrm{P}$ & Zoo & & & & 1 & & \\
\hline Senna alata & $\mathrm{Bu}$ & $\mathrm{P}$ & Aut & & & & 1 & & \\
\hline Senna spectabilis & $\operatorname{Tr}$ & $\mathrm{P}$ & Aut & & 11 & & 21 & & \\
\hline Solanum cernuum & $\mathrm{Bu}$ & $\mathrm{P}$ & Zoo & & 1 & & 6 & & \\
\hline
\end{tabular}


Table 2...

Tabela $2 \ldots$

\begin{tabular}{|c|c|c|c|c|c|c|c|c|c|}
\hline$\overline{\text { Solanum sp. }}$ & $\mathrm{Tr}$ & $\mathrm{P}$ & $\mathrm{ZoO}$ & 1 & $\overline{4}$ & & & & \\
\hline Solanum leucodendron & $\operatorname{Tr}$ & $\mathrm{P}$ & Zoo & & & & 2 & & \\
\hline Solanum mauritianum & $\mathrm{Tr}$ & $\mathrm{P}$ & Zoo & 2 & 92 & & 64 & 1 & 5 \\
\hline Solanum Swartzianum & $\mathrm{Bu}$ & $\mathrm{P}$ & Zoo & & 1 & & 7 & & \\
\hline Vernonanthura diffusa & $\mathrm{Tr}$ & $\mathrm{P}$ & Ane & & 2 & 1 & 2 & 1 & \\
\hline Vernonia polyanthes & $\operatorname{Tr}$ & $\mathrm{P}$ & Ane & & 7 & & 7 & 2 & \\
\hline Total de individuals & & & & 5 & 153 & 9 & 144 & 14 & 6 \\
\hline
\end{tabular}

Source: research data.

Source: research data.
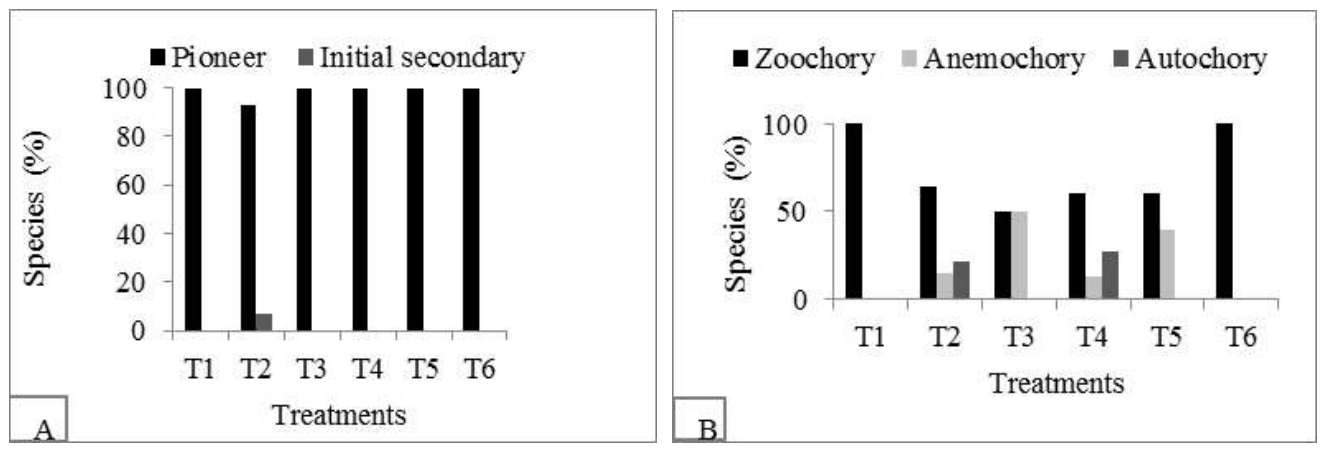

Figure 1 - Description of species after forest restoration according to succession group (A) and dispersion type (B) per treatment. T1- liming, T2- seed bank and litter transposition, T3- direct-seeding, T4-liming + seed bank and litter transposition, T5-liming + direct-seeding, T6- control.

Figura 1 - Caracterização das espécies, após a restauração, quanto ao grupo sucessional (A) e síndrome de dispersão (B) por tratamento. T1-calagem, T2-Transposição banco de sementes e serapilheira, T3-semeadura direta, T4calagem+transposição banco de sementes e serapilheira, T5-calagem + semeadura, T6-Testemunha.

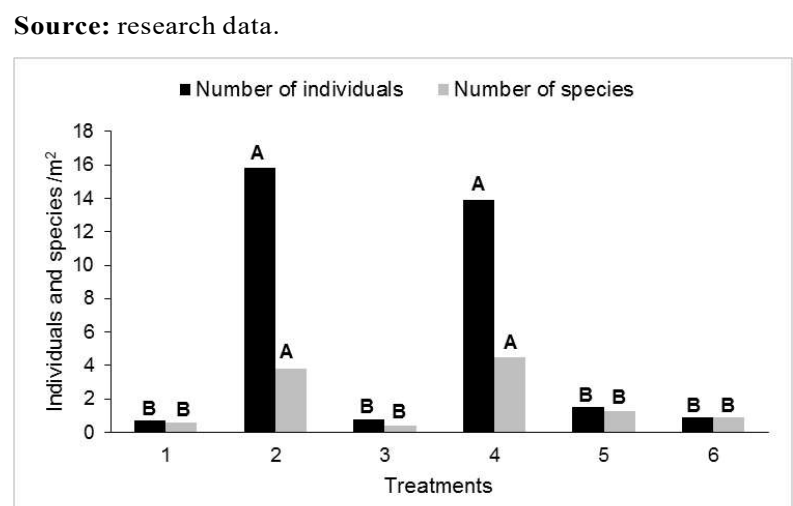

Figure 2 - Mean number of plants and of species per $\mathrm{m}^{2}$, in the different treatments: T1- liming, T2- seed bank and litter transposition, T3- direct-seeding, T4-liming + seed bank and litter transposition, T5-liming + direct-seeding, T6- control. Means followed by different letters differ significantly by the Tukey test at $5 \%$ of probability. Standard deviations for the number of plants and species, respectively: T1 $=0.2$ and $0.1 ; \mathrm{T} 2=2.9$ and 1.0 ; $\mathrm{T} 3=0.2$ and $0.1 ; \mathrm{T} 4=3.0$ and $0.8 ; \mathrm{T} 5=0.3$ and $0.2 ; \mathrm{T} 6=0.2$ and 0.1 .

Figura 2-Médias do número de indivíduos e do número de espécies, por $m^{2}$, nos diferentes tratamentos: 1-calagem, 2- Transposição banco de sementes e serapilheira, 3- semeadura direta, 4- calagem +transposição banco de sementes e serapilheira, 5-calagem+semeadura, 6-Testemunha. Médias seguidas de letras diferentes diferem significativamente entre si, ao nível de $5 \%$ de significância pelo Teste de Tukey. Desvios padrão para número de indivíduos e de espécies, respectivamente: $T 1=0,2$ e 0,$1 ; T 2=2,9$ e 1,0;T3=0,2 e 0,$1 ; T 4=3,0$ e 0,$8 ; T 5=0,3$ e 0,$2 ; T 6=0,2$ e 0,1 . 
Table 3 - Mean percentage of soil cover of plots with herbaceous and gramineous species (A) and average plant height and diameter (B) in the treatments: T1- liming, T2- seed bank and litter transposition, T3- direct-sowing, T4liming + seed bank and litter transposition, T5-liming + direct-seeding, T6- control. Means followed by different letters in the column differ statistically from one another by the Tukey test at $5 \%$ of probability. Numbers in parentheses represent standard deviation.

Tabela 3 - Médias porcentuais da cobertura das parcelas com espécies herbáceas e gramíneas (A) e Médias de altura e diametro nos tratamentos (B) nos tratamentos: T1-calagem, T2-Transposição banco de sementes e serapilheira, T3-semeadura direta, T4-calagem + transposição banco de sementes e serapilheira, T5-calagem+semeadura, T6-Testemunha. Médias seguidas por letras diferentes na coluna diferem estatisticamente entre si, pelo teste de Tukey, ao nível de 5\% de significância. Números entre parênteses representam o desvio-padrão.

\begin{tabular}{|c|c|c|c|}
\hline \multicolumn{4}{|c|}{ (A) Life Form } \\
\hline Treatments & Herbaceous (\%) & Gramineous (\%) & (Herbaceous + Gramineous) \\
\hline 1 & 70 & 30 & $100 \mathrm{~A}(4,7)$ \\
\hline 6 & 95 & 5 & $100 \mathrm{~A}(9,5)$ \\
\hline 3 & 70 & 25 & $95 \mathrm{~A}(7,6)$ \\
\hline 5 & 65 & 28 & 93 A $(7,3)$ \\
\hline 2 & 30 & 10 & $40 \mathrm{~B}(6,1)$ \\
\hline 4 & 6 & 24 & $30 \mathrm{~B}(8,1)$ \\
\hline \multicolumn{4}{|c|}{ (B)Variables } \\
\hline Treatments & \multicolumn{2}{|c|}{ Height (Centimeters) } & Diameter (Centimeters) \\
\hline 4 & \multicolumn{2}{|c|}{66,92 A $(9,60)$} & $1,06 \mathrm{~A}(0,300)$ \\
\hline 2 & \multicolumn{2}{|c|}{62,81 A $(11,3)$} & 1,02 A $(0,250)$ \\
\hline 6 & \multicolumn{2}{|c|}{39,00 B $(7,30)$} & 0,73 AB $(0,150)$ \\
\hline 1 & \multicolumn{2}{|c|}{33,20 B $(9,10)$} & 0,70 AB $(0,120)$ \\
\hline 5 & \multicolumn{2}{|c|}{$2,600 \mathrm{C}(0,40)$} & 0,35 B $(0,007)$ \\
\hline 3 & \multicolumn{2}{|c|}{$2,230 \mathrm{C}(0,31)$} & 0,29 B $(0,009)$ \\
\hline
\end{tabular}

Source: research data.

$\operatorname{Index}(\mathrm{V})=6.8 \%$; Organic Matter $(\mathrm{OM})=5.15 \mathrm{dag} /$ $\mathrm{kg}$, Remaining phosphorus $(\mathrm{P}-\mathrm{rem})=15.9 \mathrm{mg} / \mathrm{L}$.

\section{DISCUSSION}

The nucleation techniques were adequate to trigger the process of ecological succession in the area dominated by $P$. aquilinum since a significant increase of shrubarboreal individuals (331) was found in an area that had been stagnant for 50 years. Studies using nucleation techniques in abandoned pastures (Miranda Neto et al., 2010) and in mined areas (Cardozo, 2006) were found. However, no study was found using these techniques in areas dominated by P. aquilinum, so this is a pioneering study. In this way, the use of these techniques emerges as a promising methodology for the recovery of such environments.

As shown by the Shannon-Wiener's index (1.96), it was found that species diversity in the plots was low. However, as the succession progresses, an increase in the number and diversity of species is expected due to the improvement in the ecological functions and conditions of the area, such as nutrient cycling, soil fertility and shading, following a successional model of facilitation (Connell and Slatyer, 1977). Equability value (J') (0.6) showed that the plots are floristically heterogeneous, that is, with low ecological dominance. However, the study shows an average dominance exerted by the species Solanum mauritianum, which belongs to the family Solanaceae.

Solanaceae family is commonly found in the early stages of succession in degraded areas (Araújo et al., 2006). When evaluating the natural regeneration in clearings of anthropic origin, Arzolla (2011) verified that Solanaceae and Euphorbiaceae are among the families with greater species richness and that the richest genus was Solanum, as in this study. Several species belonging to the family Solanaceae, among them Solanum mauritianum, present interaction with fruit bats, functioning as nucleating species that facilitate forest restoration in open areas (Mello, 2007).

As for the number of individuals, the Solanaceae family stood out as well, followed by Fabaceae family. Miranda Neto et al. (2010), when studying the transposition of the seed bank of forest (early and mature) to an abandoned pasture in Reserva Mata do

Revista Árvore. 2017;41(1):e410104 
Paraíso also verified that the Fabaceae family was one of those that presented the highest number of individuals. This family presents several species that form symbiosis with atmospheric nitrogen fixing bacteria $\left(\mathrm{N}_{2}\right)$, being important in the process of restoration of areas with low fertility soils, such as those found in the areas dominated by P. aquilinum (Silva and Silva-Matos, 2006).

Predominance of pioneer shrub-tree species was found in the plots, most of which came from the transposed seed bank. The large number of pioneer seeds in the seed bank is due to large seed production, to efficient dispersion mechanisms and to the ability of forming a persistent bank due to long seed viability (Dalling, 2002). Some studies in seasonal semideciduous forest (Martins, 2009b; Miranda Neto et al., 2010; Arzolla, 2011) also showed the same results, evidencing the contribution of the pioneer species in the forest restoration. The greater proportion of pioneers demonstrates that in a few years the vegetation may be replaced by other species at more advanced stages of succession (Rodrigues et al., 2010) since the area dominated by Pteridium in the Caparaó National Park is surrounded by secondary forest in an advanced stage of regeneration, being able to supply propagules of later species. The absence of late secondary species in the seed bank may be attributed to the fact that the pioneers species are those that form a persistent bank, since the final succession species tend to not form a bank, or to form a short-duration transitory bank (Martins, 2009a).

The focus in this study on zoochoryc species supports the studies of other authors on soil regeneration and seed bank (Martins et al., 2008). The advantage of the predominance of zoochoryc species is that the dispersers will frequent the area, increasing the chance of new species coming from various forest fragments, which will contribute to increase the diversity of species.

In spite of a smaller quantity, it was found in all treatments, the entrance of shrubby-tree species through dispersion, simply because of the opening clearings in the area, which provided an improvement in the environment. But only the opening of clearings would not be enough to trigger the process of succession in the area. Miranda Neto et al. (2010), when evaluating control clearing (with no seed bank transposition) opened in abandoned pasture, did not find any shrub-tree species. Therefore, the authors also considered that the opening of clearings, without the introduction of seed or seedlings, is inefficient to be used as a forest restoration methodology since the simple removal of Melinis minutiflora did not allow the colonization by shrubby-tree species.

Seed bank treatments ( 2 and 4 ) were significantly superior to the others. Besides the possibility of containing high floristic richness and viable seed density and also for promoting the enhancement in soil conditions due to the increase of organic matter, nutrients and microorganisms, soil seed bank transposition is an alternative of forest restoration in degraded areas with low financial cost (Martins 2009a) and therefore, it has been widely used. A factor that must be observed when carrying out seed bank transposition is the existence and density of aggressive exotic grasses, as this may inhibit succession rather than stimulate it (Rodrigues et al., 2010).

Removal of seed bank is recommended for areas where vegetation will be suppressed (Martins et al., 2007), but these results have shown that seed bank transposition may be feasible for restoration of protected areas since the benefits obtained in a highly anthropized area, such as the area of this study, which has been completely dominated by Pteridium aquilinum for more than 50 years, compensates for the minimal impacts caused in the forest where the seed bank was removed and also because the forest where the seed bank was removed is in an advanced stage of regeneration, rapidly absorbing the small impact suffered. The important thing is that the seed bank should be removed in small plots $(1 \times 1 \mathrm{~m})$ separated from each other and authorized by the competent environmental agency.

In the treatments with seed banks ( 2 and 4 ), a higher increase of shrub-tree species was found therefore contributing to a significant reduction of grass and herbaceous species due to a greater shading of the area. In contrast, treatments $1,3,5$ and 6 had a much lower number of shrub-tree species and a higher percentage of herbaceous cover. Miranda Neto et al. (2010) observed similar results in studies with seed bank transposition in abandoned pasture.

Another factor that may have contributed to the reduction of herbaceous species in the treatments with seed bank was the use of litter on them. When the litter layer is placed over the seed bank in the degraded area, it is possible to create a physical barrier, preventing 
germination and establishment of seedlings of herbaceous species (Rodrigues et al., 2010).

The highest growth in plant height, in treatments 2 and 4 may have been caused by the presence of litter, which improves soil quality. Litter is a source of organic matter and nutrients for the viable seeds in the bank, besides increasing the infiltration and retention of water from the rains, giving it slowly to the soil, which may contribute not only to a more abundant germination (Rodrigues et al., 2010), as well as for seedling growth (Mendonça and Lourdes, 1995).

By comparing treatment 2 with 4, no significant statistical difference between the average heights of the plants was found, although treatment 4 was numerically superior. Regarding treatment 2 , liming was not performed before seed bank transposition. Thus, it was verified that the acid $\mathrm{pH}$ (4.79) of the soil did not interfere in the establishment and growth of the shrub-tree species in the plots of this treatment. It is important to consider that the transposition of the seed bank together with the litter may have greatly contributed to the improvement of soil condition.

However, correction of acid soils by liming technique is important because soil $\mathrm{pH}$ influences the decomposition of organic matter. Most of the microorganisms (fungi, actinomycetes and bacteria) of the soil have their optimal $\mathrm{pH}$ of action around neutralization (Mendonça and Lourdes, 1995). Thus, $\mathrm{pH}$ correction favors microbial activity and accelerates the decomposition of organic matter.

Higher plant height growth in the nuclei is important in the competition with $P$. aquilinum. It is expected that over time, the shrub-tree species will come to shade the fern, reducing their proliferation in the area, considering that the species is shade-intolerant.

In relation to diameter from up ground (DAS), treatments with seed bank ( 2 and 4 ) did not differ statistically from 1 (liming) and 6 (control). However, despite these results, the amount of individuals was significantly lower in treatments that did not involve the use of the seed bank.

By comparing the values found in the soil analysis of the area dominated by P. Aquilinum with the one proposed by Ribeiro et al. (1999), it was found that the soil in the study area is acid and has low availability of essential nutrients. In addition, these environments are proner to invasion by $P$. aquilinum (Tokarnia et al., 2000).

The organic matter content was adequate $(5.15$ $\mathrm{dag} / \mathrm{kg}$ ) in comparison with the classification of Ribeiro et al. (1999). The organic matter of the soil is composed, almost completely, of plant residues whose composition varies between different species (Mendonça and Lourdes, 1995). However, the organic matter of this area is basically composed by the cover of the fern litter, and cannot be considered as an indication of good soil quality.

The presence of this species is very common on the edges of the forests, on the roadside, in forest clearings and in the agricultural areas around the Caparaó Park, showing that together with soil conditions, the disturbance factor is also important in the process of colonization, establishment and dissemination of $P$. aquilinum.

The occurrence of fires at Caparaó National Park is frequent and it contributes to soil impoverishment and the invasion of $P$. aquilinum. Moreover, in the clearings dominated by it, there is a tendency to increase the frequency of fires due to the dense layer of the formed biomass (SILVA-MATOS; BELINATO, 2010), impoverishing even more the soil and favoring $P$. aquilinum, which in addition to growing well on poor and acid soils, it even has its buds stimulated by fire. The sloping areas and abundant rains of the Caparaó National Park region also contribute to the impoverishment of the degraded areas, because with the exposure of the soil, the nutrients can be easily leached.

The low germination of Araucaria angustifolia seeds in the treatments with sowing ( 3 and 5), can be explained by the fact that irrigation was not performed and due to the occurrence of predation by rodents, factors that may occur in nature. In addition to the low germination, germinated Araucaria angustifolia seedlings did not develop well. As the nucleation techniques, in areas dominated by Pteridium aquilinum, are innovative, further studies with sowing should be carried out for testing other species.

\section{CONCLUSIONS}

The nucleation techniques adopted in this study triggered the succession process in the area invaded by Pteridium aquilinum. The treatments with seed

Revista Árvore. 2017;41(1):e410104 
bank were the most indicated to facilitate the process of forest regeneration in the area, considering that they presented greater richness and abundance of species. Lower coverage with herbaceous, grass and creeper species were found in them, besides a higher plant height growth compared to the other treatments.

Thus, the practice of seed bank transposition is recommended as a methodology for forest restoration in areas dominated by Pteridium aquilinum. However, this methodology is indicated for areas where environmental licensing has authorized the suppression of vegetation. Nevertheless, the results of this research also create a possibility that seed bank transposition can be carried out in degraded areas in Conservation Units as long as authorized by the competent environmental agency.

Regarding treatments with seed planting, it is necessary to perform tests with other species and also with Araucaria angustifolia because its germination did not reach $5 \%$.

\section{ACKNOWLEDGEMTNS}

To Fapemig, for granting a doctorate scholarship to the first author; to CNPq, for the Research Productivity grant to the second author; and to the National Park of Caparaó (ICMbio), for the authorization of the research and the logistical.

\section{REFERENCES}

Angiosperm Phylogeny Group III - APG III. An update of the Angiosperm Phylogeny Group classification for the orders and families of flowering plants: APGIII. Botanical Journal of the Linnean Society. 2009;161(2):105-21.

Araújo FS, Martins SV, Meira Neto JAA, Lani JL, Pires IE. Estrutura da vegetação arbustivo-arbórea colonizadora de uma área degradada por mineração de caulim, Brás Pires, MG. Revista Árvore. 2006;30(1):107-16.

Arzolla FARDP. Florestas secundárias e a regeneração natural de clareiras antrópicas na Serra da Cantareira, SP [tese]. Campinas: Universidade Estadual de Campinas; 2011. 141p.

Cardozo JS. Proposta de modelo para reabilitação de área degradada pela extração de argila e areia no município de Morro de Fumaça, SC [monografia]. Criciúma: Universidade do Extremo Sul Catarinense; 2006. 77p.

Connell JH, Slatyer RO. Mechanisms of succession in natural communities and their role in community stability and organization. American Naturalist. 1977;111(982):1119-44.

Dalling JW, Hubbell SP, Silvera K. Seed dispersal, seedling establishment and gap partitioning among tropical pioneer trees. Journal of Ecology. 1998;86(4):674-89.

Den Ouden, J. The role of bracken (Pteridium quilinum) in forest dynamics. Dordrecht: Wageningen University; 2000. 218p.

Instituto Brasileiro do Meio Ambiente e dos Recursos Naturais Renováveis - IBAMA. Unidade: Parque Nacional do Caparaó. Brasília: 2004. 90 p. [acessado: 30 nov. 2013] Disponível: ngu// www.ibama.gov.br.

Lorenzi H. Pteridium aquilinum (L.) Kuhn. Nova Odessa: Instituto Plantarum; 1991. Plantas daninhas do Brasil: terrestres, aquáticas, tóxicas e medicinais; p.341

Marrs RH, Watt AS. Biological flora of the British Isles: Pteridium aquilinum (L.) Kuhn. Journal of Ecology, 2006;94(6):1272-321.

Magurran AE. Ecological diversity and its measurement. London: Croom Hell; 1988. 179p.

Martins SV, Rodrigues RR. Gap-phase regeneration in a semideciduous mesophytic forest, southeastern Brazil. Plant Ecology. 2002;163(1):51-62.

Martins SV. Recuperação de matas ciliares. Viçosa, MG: Aprenda Fácil; 2007. 255p.

Martins SV, Almeida DP, Fernandes LV, Ribeiro TM. Banco de sementes como indicador de restauração de uma área degradada por mineração de caulim em Brás Pires, MG. Revista Árvore. 2008;32(6):1081-8.

Martins SV. Recuperação de áreas degradadas: ações em Áreas de Preservação Permanente, voçorocas, taludes rodoviários e de mineração. Viçosa, MG: Aprenda Fácil; 2009a. 270p.

Martins SV. Soil seed bank as indicator of forest regeneration potential in canopy gaps of a 
semideciduous forest in Southeastern Brazil. In: Fournier MV, editor. Forest regeneration: ecology, management and economics. New York: Science Publishers; 2009b. p.113-28.

Mello MAR. Morcegos e frutos: interação que gera florestas. Ciência Hoje. 2007;41(241):30-5.

Mendonça ES, Loures EG. Matéria orgânica do solo. Brasília: ABEAS; 1995. 45p.

Miranda Neto A, Kunz SH, Martins SV, Silva KA, Silva DA. Transposição do banco de sementes do solo como metodologia de restauração florestal de pastagem abandonada em Viçosa, MG. Revista Árvore. 2010;34(6):1035-43.

Mueller-Dombois D, Ellenberg H. Aims and methods of vegetation ecology. New York: John Wiley; 1974. 547p.

Pielou EC. Ecological diversity. New York: Johon Willey; 1975. 165p.

Rodrigues BD, Martins SV, Leite HG. Avaliação do potencial da transposição da serapilheira e do banco de sementes do solo para restauração florestal em áreas degradadas. Revista Árvore. 2010;34(1):65-73.

Ribeiro AC, Guimarães PTG, Alvarez V VH, editores. Recomendações para o uso de corretivos e fertilizantes em Minas Gerais. Viçosa, $\mathrm{MG}$ : CFSEMG: 1999.359p.

Shepherd GJ. Fitopac 2.1 - Campinas: Universidade Estadual de Campinas; 2010.

Silva USR, Silva-Matos DM. The invasion of Pteridium aquilinum and the impoverishment of the seed bank in fire prone areas of Brazilian Atlantic Forest. Biodiversity and Conservation. 2006;15(9):3035-43.

Silva-Matos DM, Belinato TA. Interference of Pteridium arachnoideum (Kaulf.) Maxon. (Dennstaedtiaceae) on the establishment of rainforest trees. Brazilian Journal of Biology, 2010;70(2):311-6.

Statsoft, INC. Statistica - Data analysis software system. Version 7.0.61.0. Tulsa: 2004.

Tokarnia CH, Döbereiner J. Plantas de ação radiomimética. Rio de Janeiro: Helianthus; 2000. Plantas Tóxicas do Brasil. p.178-85.

van der Pijl, L. Principles of dispersal in higher plants. $3^{\text {rd }}$. ed. New York: Springer-Verlag; 1982. $214 p$.

Veloso HP, Rangel Filho ALR, Lima JCA.

Classificação da vegetação brasileira, adaptada a um sistema universal. Rio de Janeiro: IBGE; 1991. 123p.

\section{ERRATA}

No artigo "ECOLOGICAL RESTAURATION IN AREA DOMINATED BY Pteridium aquilinum (L.) Kuhn IN CAPARAÓ NATIONAL PARK, MG”, publicado no número 1, volume 41, da Revista Árvore, onde se lê:

ECOLOGICAL RESTAURATION IN AREA DOMINATED BY Pteridium aquilinum (L.) Kuhn IN CAPARAÓ NATIONAL PARK, MG

L eia- s e:

\section{ECOLOGICAL RESTORATION IN AREA DOMINATED BY Pteridium aquilinum (L.) Kuhn IN CAPARAÓ NATIONAL PARK, MG}

